\title{
Teaching Corporate Social Responsibility In An MBA Program
}

Geoffrey Tickell, Indiana University of Pennsylvania, USA

Veronica Paz, Indiana University of Pennsylvania, USA

Monsurur Rahman, Indiana University of Pennsylvania, USA

\begin{abstract}
This paper discusses the topic of corporate social responsibility (CSR) and proposes that CSR should be taught in an MBA program and, more specifically, in a Managerial Accounting course of an MBA program. CSR aligns strongly with other managerial accounting topics typically taught in an MBA Program such as the balanced scorecard and triple-bottom line reporting. In putting forward this suggestion, this paper proposes a definition of CSR, reviews recent literature relating to CSR, and provides several strategies for teaching and assessing students' understanding and appreciation of CSR. In the results section of the paper, a content analysis of student essays provides an insight into how students view CSR. The paper concludes with an overview of what is attainable by teaching CSR in a Managerial Accounting MBA course.
\end{abstract}

Keywords: Corporate Social Responsibility; Managerial Accounting; Sustainability; MBA Courses

\section{INTRODUCTION}

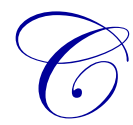

orporate social responsibility, usually referred to as CSR, has received many attempts by researchers to define the term (Carroll, 1999; Dahlsrud, 2008). However, almost all definitions indicate that CSR occurs when a business takes action that goes beyond its financial objectives and undertakes measures that consider the impact its decisions might have on stakeholders. Unlike the centuries- old concepts of profitability, solvency, and liquidity, CSR is a relatively new business objective. It is quite apparent that it is only in the last 50 years or so that corporate leaders have considered the effect their business decisions will have upon the stakeholders of that corporation (Popular Pittsburgh, 2016; Sherman, 2002).

Providing students with an understanding and appreciation of CSR should be an objective of an MBA program. The course of best fit for such a topic is Managerial Accounting. Concepts such as triple-bottom-line reporting and the balanced scorecard are usually covered in a managerial accounting course and CSR aligns closely with those topics. In fact, the Association to Advance Collegiate Schools of Business (AACSB) (AACSB, 2004) and the Institute of Management Accountants (IMA) (Verschmoor, 2016) have strongly indicated that they expect ethics and CSR to be taught in accounting courses.

CSR, as a topic within a course, is flexible and can be taught and assessed in a multitude of methodologies and with a range of depths. Consideration does need to be given by the professor to the skills, the knowledge and the enthusiasm of the student group when developing the teaching and assessment approach to be taken. Furthermore, CSR is highly adaptable. For example, CSR could be approached from a positive or negative perspective (e.g., philanthropic ventures versus unsafe work-practices), using a small-scale or large-scale approach (e.g., local business versus a multinational corporation), investigating local or global practices (e.g., one rainforest versus global warming), theoretically- or practically-focused (e.g., the effect on long-term earnings versus one year's sales data), and with an historical, present or future orientation (e.g., CSR in the 1920's versus 2010 or 2050).

The assessment tool used for evaluating CSR student knowledge is also flexible and adaptable and could require surface or deep-learning skills, analysis of a case-study or drawing on personal experience, through written or oral assessment, or with regards to all stakeholders in general or specific to only one category of stakeholder (e.g., the work-site's neighbors). 
The instructor would determine the approach after considering the objectives of the course and the quality and enthusiasm of the students. Furthermore, CSR has sufficient adaptability to allow the instructor to have as much or as little involvement as he/she chooses. Flexibility and adaptability are features of this important topic.

This paper is designed as follows. After the introduction, the next section undertakes a review of recent literature pertaining to CSR. The method section outlines the means by which the present authors teach and assess student learning of CSR. This includes the project requirements, a rubric used to assess each the student's effort, and the approach taken for a content analysis of student essays (Berg, 2004). This section also suggests other methods by which the concept could be taught and assessed. The results section summarizes findings from a content analysis undertaken by the authors outlining the learning achieved by the students and a mind map (Bazely, 2002). The final section, the conclusion, summarizes what the present authors have learned from teaching and assessing CSR in an MBA Managerial Accounting course.

\section{LITERATURE REVIEW}

In many ways, CSR is a continuum. What a corporation regarded as a magnanimous CSR gesture fifty or so years ago would most likely be regarded by today's stakeholders as grossly inadequate (Claydon, 2011). The direction of the trend in CSR is irrefutable. Great strides have been made in the last fifty years in policies relating to equalopportunity employment, workers' rights, consumers' rights, product-quality, environmental protection, and tradepractices (Campbell, 2007). All of the elements of today's typical business practices in many parts of the world can be regarded as reflecting the principles of CSR; that is, thinking beyond the bottom-line. However, there is still much to be learned and implemented by directors and managers of corporations with regards to CSR. It is not uncommon to read an article in a national newspaper that details a policy that breaches corporate social responsibility.

What is CSR? In 1980, Jones defined CSR as "the notion that corporations have an obligation to constituent groups in society other than stockholders and beyond that prescribed by law and union contract" (Jones, 1980, p. 59). In 1991, Carroll illustrated CSR as a pyramid with economic outcomes at the base and legal, ethical, and philanthropic categories being placed in that order above economics (Carroll, 1991). Later Carroll stated that CSR involves the conduct of business so that it is economically profitable, law abiding, ethical and socially supportive (Carroll, 1999). Fast forward a few years and we see that the International Organization for Standardization (ISO) describes CSR as a "balanced approach for organizations to address economic, social and environmental issues in a way that aims to benefit people, communities, and society" (see Leonard \& McAdam, 2003, p. 27). Furthermore, the ISO states that CSR includes consideration of issues such as human rights, occupational health and safety, unfair business practices, organizational governance and environmental aspects (Leonard \& McAdam, 2003). The European Commission defines CSR as companies taking responsibility for their impact on society (Boston, 2016). Finally, Caramela (2016) defines CSR most succinctly as "business practices involving initiatives that benefit society" (p. 1).

Although a variety of themes are evident in the above definitions, the direction of the trend is irrefutable. Firstly, corporate profitability is key and the starting point. Long-term CSR can only occur when a corporation is economically viable. To some extent, this could be what the economist Milton Friedman was alluding to in 1970 when he asserted, "the social responsibility of business is to increase profits" (Friedman, 1970, p. 32). Much more recently, Fassin, Van Rossem, and Buelens (2011) indicate that a stock's value and CSR are complementary and, in fact, are "mutually reinforcing" (p. 443). A recent case-in-point is that of Tesla, the automobile manufacturer. It's zero-emission and highly rated vehicles have resulted in Tesla having over 400,000 advance orders for their vehicles (Befeki \& Epstein, 2016).

The second theme is that CSR is somewhat voluntary. This is especially so when it comes to philanthropic actions. One positive example is that of Wal-Mart, FedEx, Home Depot, and other US companies coming together to provide victims of Hurricane Katrina with disaster relief to the value of $\$ 792$ million less than a month after the disaster struck (Matten \& Moon, 2008). Their response was driven by humanitarian rather than profit motives.

It is evident from corporate websites and annual reports that Boards of Directors, with the assistance of their accountants, have started to measure and report on the CSR practices of their corporation. Terms such as "the balanced scorecard" and "triple-bottom-line" are often referred to when CSR is discussed (e.g., see Weygandt, 
Kimmel, \& Kieso, 2015). The balanced scorecard uses both financial and nonfinancial measures to evaluate a company's overall performance by utilizing four perspectives from which decision-makers can assess the effectiveness of a company's policies and achievements. The four perspectives are: (i) learning and growth, (ii) business processes, (iii) the customer, and (iv) the financial perspective (Weygandt et al., 2015).

Triple-bottom-line reporting incorporates an entity's economic, environmental and social performance results into reports presented to management (Elkington, 1997). The triple bottom line is often referred to as the three p's; profit, planet and people. More recently, terms such as "sustainability management accounting system", "environmental management accounting", "social management accounting" have developed as measures of a firm's impact on society beyond the financial statements (Petcharat, 2014). These terms, as used by organizations, are in their infancy and their definitions are not necessarily clear and agreed upon yet. However, the Sustainability Accounting Standards Board (SASB) has developed sector-specific metrics allowing sustainability to be included in the Form 10-K; a corporation's Annual Report required by the U.S. Securities and Exchange Commission (Befeki \& Epstein, 2016).

Furthermore, whereas in the past, CSR might have been regarded by the Board of Directors to be outside the core operations of their business and used for philanthropic and public relations purposes (e.g., the Ronald McDonald house for the McDonald's fast-food franchise), boards today are aligning CSR within their core business; that is, they see that positive CSR attitudes and actions lead to long-term profits and overall business sustainability. There is substantial empirical research showing that effective CSR practices by a corporation lead to long-term financial rewards for the stockholders of that corporation (Husted \& Allen, 2007). It is noted by Husted and Allen (2007) that "looking after the people and the community as well as the environment are all relevant to long-term business survival" (see D'Amato, Henderson, \& Florence, 2009, p. 5). In contrast, the complete opposite can occur when the actions of the leader(s) of that corporation are seen to be in conflict with the corporation's public image. A case-inpoint would be that of Lance Armstrong and his "Livestrong Foundation". Although the Foundation still exists, revenues have fallen dramatically since Armstrong, the cancer charity's founder and former chairman, confessed to and found guilty of taking performance-enhancing drugs during his very successful cycling career (Schrotenboer, 2016).

Today, CSR is morphing into a variety of titles. For example, the most prominent pseudonym at present is "sustainability". Often the terms CSR and sustainability are interchangeable. There are many organizations opening their doors as sustainability forums (e.g., the CSR \& Sustainabilty Insitute, CaSI, 2016) arguing that the only future for business is that of being a sustainable business.

The AASCB encourages business schools to teach CSR in their programs (AACSB, 2004). The Institute of Management Accountants (IMA) states that "management accountants in organizations of all sizes and ownership patterns should listen to and be prepared to lead their organizations as the (sustainability) conversation evolves" (Verschmoor, 2016, p. 16).

Given that CSR is becoming main-stream in corporate decisions, and that the AACSB and the IMA are expecting Colleges to teach CSR in their programs, the next section of the paper outlines the approach taken by the present authors to teach and assess CSR as a topic within a Managerial Accounting course of an MBA program.

\section{TEACHING METHODOLOGY}

\subsection{Part I: Our Approach}

The College of Business at our university decided over five years ago to introduce CSR as a learning objective into our Managerial Accounting course in the MBA Program. The relevant objective in the syllabus states, "At the completion of this course students will be able to ... analyze corporate social responsibility and ethics issues confronting organizations and recommend ethically responsible actions". The Department of Accounting was charged with teaching and developing the assessment tool to satisfy this objective. The present authors decided to tackle the objective in two parts; the first is an essay on CSR while the second involves a case-study on unethical behavior in a manufacturing plant. The present paper focuses on the first part; the CSR essay. 
One consideration before teaching CSR in an MBA class is to determine the sub-objectives to be achieved via the assessment. As mentioned earlier, CSR is a flexible topic and can be taught in a variety of methods. There are many factors that the instructor should consider when determining how and what to teach, how and what to assess, and at what difficulty-level to grade student work. Whatever approach the instructor uses, it is important that students are motivated and inspired by the learning process and the assessment tool so that they find the task challenging, interesting and rewarding. Furthermore, we suggest that irrespective of the form the assessment takes, student work should show evidence of considerable research, be original, logical, coherent and interesting. It is these qualities that should determine the grade.

As outlined in Exhibit 1, we teach CSR by requiring students to write a 500 -word essay explaining the CSR initiatives undertaken by a company of their choosing. It is important that the company each student selects has an active and detailed website pertaining to the area of CSR so that the instructor can verify the website for details noted by the student. The first requirement of the assessment is for students to research the literature to develop their definition of CSR. Students then choose a company that interests them sufficiently to research and write about that company's CSR activities. Preferably, they will choose a company they have a personal connection with and will include in their essay features of that personal connection. For example, they might select the company they presently work for. As our students are Executive MBA students with at least five years of work-experience, it is possible that they will be working for a company that undertakes CSR activities. Or, as a citizen of their local community, they might have a personal involvement in a CSR activity that a local business has put in place. Alternatively, they might have a family member or a friend who is a recipient of a CSR project and the student can write about the benefit their relative or friend received from the CSR activities of that company. One objective of the project is to stimulate the student's interest in CSR and allow them to become engaged with their research and their writing thereby enabling a deeper connection to the topic.

Exhibit 1. The Assessment

Using resources available on the Web, you are required to write a 500 word essay on Corporate Social Responsibility. You are required to:

a) Provide your own definition of what is meant by Corporate Social Responsibility (CSR)

b) Using a company you have selected, investigate and explain in your own words the corporation's efforts in aiming to be a socially responsible corporate citizen. These efforts might include any of practices focusing on human rights, resource allocation, greenhouse gas emissions, community programs, sustainable development, and other socially responsible actions. Your essay will score higher if you choose one aspect of the corporation's CSR and discuss it in depth. Personalizing your essay (e.g., you might have personal experience in one aspect of the corporation's CSR) will also increase your score. You should properly cite any sources that you use and add a reference list. Use the rubric to guide your writing.

Our assessment tool has dual motivations. First is for the students derive a more solid understanding and appreciation of CSR. Second is for students to improve their research and writing skills as they complete their essay. Requiring students to write an essay meets the objective of the American Institute of Certified Practicing Accountants (AICPA) and other professional bodies (AICPA, 2016; McDonough \& Bennett, 2006). The Accounting profession continually calls for improved written communication and presentation skills of accounting graduates (NASBA, 2008). In fact, a significant reason for accounting graduates being required by the AICPA to obtain 150 credit hours before becoming eligible to qualify as a CPA, among other requirements, is to have graduates obtain improved communication skills from the extra 30 credit hours of study (NASBA, 2008). Other professional groups in the business field also call for graduates to have improved teamwork skills, problem-solving skills and the ability to research (MBA.com, 2014).

The grading rubric (see Exhibit 2) outlines the grading scale for the essay. It rewards students for personalizing the content, well-written sentences, paragraph structure, and correct citing and referencing. These requirements are consistent with those expected by professional groups and business executives. 
Exhibit 2. Assessment Rubric for the essay on CSR

\begin{tabular}{|c|c|c|c|c|c|}
\hline Score & $\begin{array}{l}\text { Readability and } \\
\text { authenticity }\end{array}$ & $\begin{array}{l}\text { Answers the } \\
\text { question }\end{array}$ & Personalized & Length & Referencing \\
\hline 5 & $\begin{array}{l}\text { Easy to read. Flows } \\
\text { well. An interesting } \\
\text { read. }\end{array}$ & $\begin{array}{l}\text { Directly answers the } \\
\text { question. }\end{array}$ & $\begin{array}{l}\text { A direct personal } \\
\text { connection is shown. }\end{array}$ & $\begin{array}{l}\text { Within } 20 \% \text { of the } \\
\text { word-limit. }\end{array}$ & $\begin{array}{l}\text { Citations included } \\
\text { within the text. } \\
\text { References are listed } \\
\text { at the end of the text } \\
\text { and are shown fully } \\
\text { and correctly. }\end{array}$ \\
\hline 4 & $\begin{array}{l}\text { Appears to be using } \\
\text { own words. Not } \\
\text { many grammatical } \\
\text { errors. Somewhat } \\
\text { interesting. }\end{array}$ & $\begin{array}{l}\text { Mostly answers the } \\
\text { question. }\end{array}$ & $\begin{array}{l}\text { Personalization is not } \\
\text { personal but an } \\
\text { attempt has been } \\
\text { made. }\end{array}$ & $\begin{array}{l}\text { Has exceeded the } \\
500 \text { word limit by } \\
\text { more than } 20 \% \text {. }\end{array}$ & $\begin{array}{l}\text { References are listed } \\
\text { at the end of the essay } \\
\text { but not cited within } \\
\text { the text. }\end{array}$ \\
\hline 3 & $\begin{array}{l}\text { Difficult to read due } \\
\text { to grammatical } \\
\text { errors. Sentences do } \\
\text { not flow easily. } \\
\text { Uninteresting. }\end{array}$ & $\begin{array}{l}\text { Is vague in } \\
\text { answering the } \\
\text { question. }\end{array}$ & $\begin{array}{l}\text { No personalization } \\
\text { mentioned. }\end{array}$ & $\begin{array}{l}\text { Essay is between } 20- \\
50 \% \text { below the } 500 \\
\text { word expectation. }\end{array}$ & $\begin{array}{l}\text { References are } \\
\text { generic and do not } \\
\text { seem to have been } \\
\text { used to develop the } \\
\text { essay. }\end{array}$ \\
\hline 2 & $\begin{array}{l}\text { Use of own sentence } \\
\text { construction is } \\
\text { limited. Essay is dull } \\
\text { to read. }\end{array}$ & $\begin{array}{l}\text { Essay is vague in } \\
\text { answering the } \\
\text { question. }\end{array}$ & $\begin{array}{l}\text { No personalization } \\
\text { mentioned. }\end{array}$ & $\begin{array}{l}\text { Essay is between } \\
250 \text { and } 100 \text { words in } \\
\text { length. }\end{array}$ & $\begin{array}{l}\text { References are not } \\
\text { listed. }\end{array}$ \\
\hline 1 & $\begin{array}{l}\text { Strong indication of } \\
\text { cut and paste from a } \\
\text { website. }\end{array}$ & $\begin{array}{l}\text { Essay does not } \\
\text { answer the question. }\end{array}$ & $\begin{array}{l}\text { No personalization } \\
\text { mentioned. }\end{array}$ & $\begin{array}{l}\text { Essay is less than } \\
100 \text { words in length. }\end{array}$ & $\begin{array}{l}\text { References are not } \\
\text { listed. }\end{array}$ \\
\hline 0 & $\begin{array}{l}\text { Student copied } \\
\text { another student's } \\
\text { work. }\end{array}$ & $\begin{array}{l}\text { Student copied } \\
\text { another student's } \\
\text { work. }\end{array}$ & $\begin{array}{l}\text { Student copied } \\
\text { another student's } \\
\text { work. }\end{array}$ & $\begin{array}{l}\text { Student copied } \\
\text { another student's } \\
\text { work. }\end{array}$ & $\begin{array}{l}\text { Student copied } \\
\text { another student's } \\
\text { work. }\end{array}$ \\
\hline
\end{tabular}

\subsection{Part II: Other Possible Approaches}

As noted, the topic and the assessment are flexible and adaptable to the objectives of the course and program and the capabilities of the students. Alternative forms of assessment, apart from a research essay, could include a presentation (individual or group), a debate between two groups of students, an investigatory article, an opinion piece, or even the traditional quiz or exam. Examples of each include:

1. A classroom debate. Possible topics include:

- Do proactive CSR activities lead to improved financial performance?

- Is improving employee working conditions in a developing nation a CSR objective or merely effective human resources management?

- Is CSR only worthwhile when the corporation obtains a positive public image from its actions?

2. Students are required to write an opinion piece on a company where there appears to be a conflict between company policy and its CSR objectives. Examples could include:

- Cost-cutting measures that diminish the safety of a product (e.g., a General Motors and their ignition switch problem).

- Knowingly altering vehicle emission testing to meet environmental standards (e.g., Volkswagen).

- A conflict between the CSR in the US with the business practices of the corporation in developing economies (e.g., a company providing bribes to secure business in a foreign country).

- A corporation's treatment of employees in the US versus the treatment of its employees by a subsidiary in a developing nation.

3. An essay reviewing the growing number of organizations that monitor the CSR practices of corporations (e.g., (CaSI, 2016).

4. A historical piece. For students working in the government sector, CSR could be taught by looking at corporate actions and the impact on a local community. For example, toxic air pollution caused by coal mining and steel mill emissions within the city of Pittsburgh, Pennsylvania during the $19^{\text {th }}$ and early 
$20^{\text {th }}$ century is well documented. The cleanup, starting in the 1940 's, is a good example of a successful CSR government/business collaboration to reduce air pollution (Popular Pittsburgh, 2016).

It is notable that on a daily basis there are articles in newspapers divulging either a constructive or damaging CSR practice undertaken by a corporation. The instructor could lead students towards these CSR examples or require them to seek them out themselves. We suggest that the means of assessment, as determined by the instructor, should enthuse students to the extent that they want to share their effort with the instructor and their classmates and be an item of assessment they are proud to share and submit.

\section{RESULTS}

We teach CSR by requiring students to write a 500-word research essay outlining the CSR activities of a company of their choice. In the five years that we have graded the essays, we have found the following common characteristics:

1. Students prefer to select the company rather than have the instructor impose a company on them. This adds to their enthusiasm to write and share their essay.

2. Students who write their essay from personal experiences tend to write more engaging essays than students who obtain their information solely from the world-wide-web.

3. Only a small percentage of students show clear evidence of understanding how to cite and reference their essays correctly. Extra attention by the instructor is needed here. As the rubric shows (see Exhibit 2), points are deducted for a lack of proper citing and referencing.

4. There tends to be a positive association between a student's business experience and the quality of their essay.

5. There is a tendency for students with less business experience to reproduce large sections from the web. Software (Turnitin, 2016) that can detect plagiarism should be incorporated in the submission process. We use "Turn-it-in" software to scrutinize student essays for the percentage of non-originality when submitted into the electronic drop-box. Students are severely penalized for significant amounts of non-originality (see the rubric, Exhibit 2).

NVivo to create nodes to indicate a collection of references to specific themes (Bazely, 2002). This process is useful in identifying relationships between themes. The themes are represented visually using cognitive mapping including relational and spatial analyses to determine relevant semantic networks, clusters and knowledge structure of key concepts, themes and contexts (Bazely, 2002; Berg, 2004). The coding process helped to construct a coding model (see Exhibit 3). The results of the coding reveals students frame the definition of CSR as ethical decisions on a voluntary basis for societal gains. Most students identify CSR agendas around themes that we labelled environment, human rights, and occupational health and safety. 
Exhibit 3. Mind Map of CSR

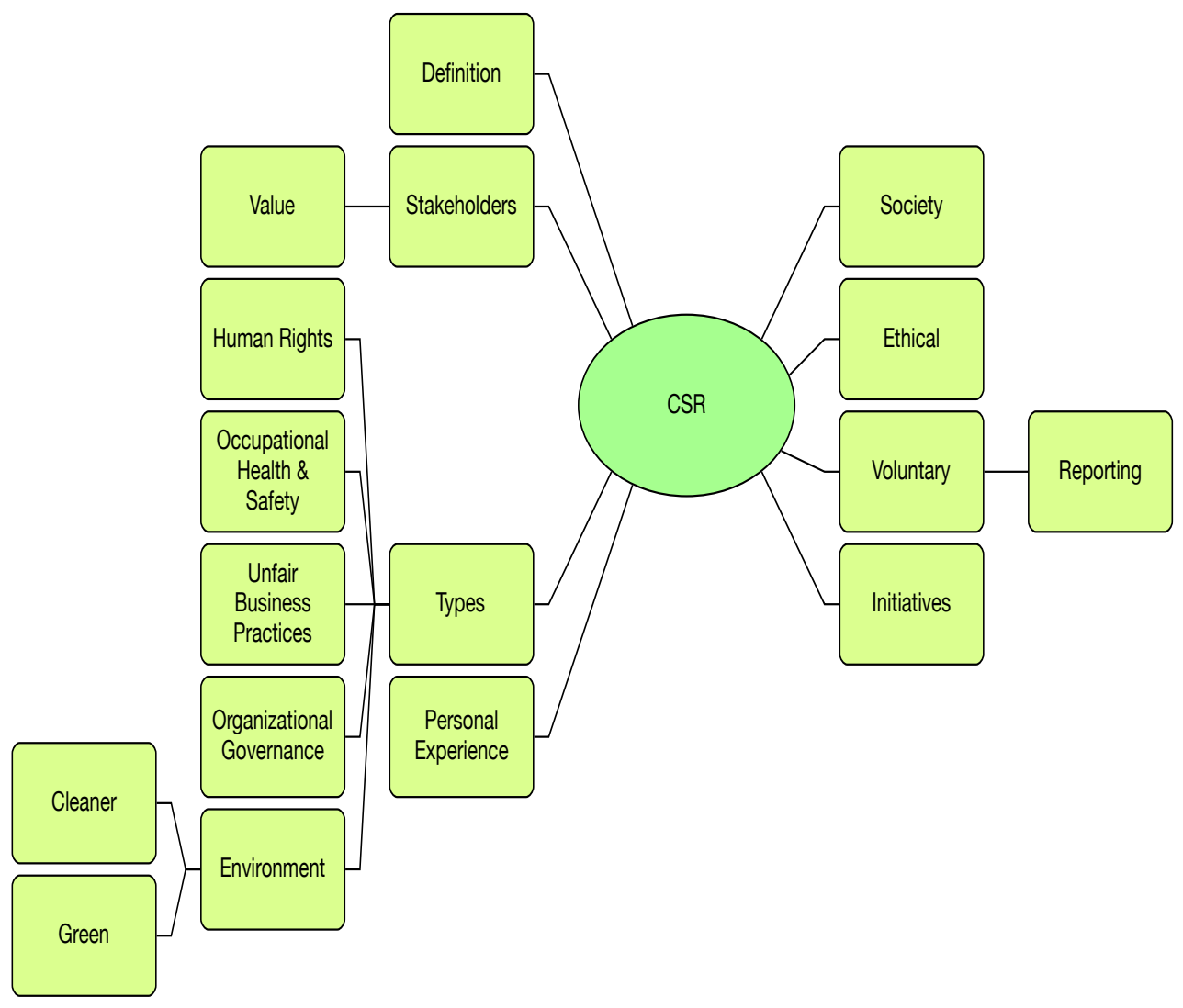

\section{CONCLUSION}

The growing emphasis on CSR over the past five or so decades suggests that CSR should be taught in an MBA curriculum. This is because CSR involves corporations being socially responsible and MBA students are currently pursuing or intending to pursue careers in management positions within corporations. The authors propose that due to the alignment of CSR with other related topics, a Managerial Accounting course is the logical place for CSR within an MBA program.

Through this paper, the authors provide the reader with a "ready-to-go" instrument and rubric for assessing students CSR knowledge. This paper also provides several suggestions as to areas that could be implemented to make the assessment more rigorous and challenging.

As a concluding comment, as well as being adaptable and flexible, the amount of time devoted to the topic of CSR is at the discretion of the instructor. While there are many topics to be taught in a Managerial Accounting MBA program, it is the position of the present authors that there should be time and space devoted to CSR. In our classroom, each professor typically devotes only 20 minutes of class time per semester to explain the assessment and the rubric; students are left to figure out the rest using the rubric as their guide.

\section{AUTHOR BIOGRAPHIES}

Geoffrey Tickell, Ph.D, CPA, is a professor of Accounting at Indiana University of Pennsylvania (IUP). He received his doctorate from Monash University, Australia. He has taught accounting courses in higher education for over 20 years. His research interests include accounting education and international accounting. E-mail: geoffrey.tickell@iup.edu. (Corresponding author). 
Veronica Paz, CPA, CITP, CFF, CGMA, is an Associate Professor of Accounting at Indiana University of Pennsylvania. She earned her Doctorate in Business Administration from Nova Southeastern University. Her research interests include, CEO compensation, earnings quality, technology in the accounting classroom, and forensic accounting. E-mail: vpaz@iup.edu

Monsurur Rahman is a Professor of Accounting at Indiana University of Pennsylvania. He received his doctorate from Southern Illinois University - Carbondale. He is a CPA and CMA. His research has been published in the National Accounting Journal, Southeast Business and Economics Journal, and Journal of Accounting and Finance Research, and many national regional conference proceedings. His research interests are in the area of Financial and Managerial Accounting. E-mail: mrahman@iup.edu

\section{REFERENCES}

AACSB. (2004). Ethics education in business schools. Tampa, Florida: Ethics Education Task Force to AACSB International's Board of Directors.

AICPA. (2016). In-demand communiction skills. Retrieved 12/04/2016, 2016, from https://www.aicpa.org/InterestAreas/YoungCPANetwork/Resources/Career/Pages/Communcation_Skills.aspx

Bazely, P. (2002). The evolution of a project involvoing an integrated analysis of structured qualitative and quantitative data from N3 to NVivo. International Journal of Social Research Methodology 5(3), 229-243.

Befeki, T., \& Epstein, M. J. (2016). 21st century sustainability. Strategic Finance, November, 28-37.

Berg, B. L. (2004). Qualititative Research Methods for the Social Sciences. Boston, MA: Pearson Education.

Boston, W. (2016, 12/06/2016). New VW tech firm to challenge Uber, Wall Street Journal.

Campbell, J. L. (2007). Why would corporations behave in socially responsible ways? An institutional theory of corporate social responsibility. The Academy of Management Review, 32(3), 946-967.

Caramela, S. (2016). What is corporate social responsibility? Business News Daily, June 27, 2016.

Carroll, A. B. (1991). The pyramid of coporate social responsibility: Toward the moral managemnment of organizational stakeholders. Business Horizons, July-August, 39-48.

Carroll, A. B. (1999). Corporate Social Responsibility: Evolution of a definitional construct. Business and Society, 38(3), 268295.

CaSI. (2016). 5.8 Monitoring impact of CSR activities. Retrieved 12/03/2016, from http://csrandsustainability.com/5-8monitoring-impact-of-csr-activities/

Claydon, J. (2011). A new direction for CSR: the shortcomings of previous CSR models and the rationale for a new model. Social Responsibility Journal, 7(3), 405-420.

D'Amato, A., Henderson, S., \& Florence, S. (2009). Corprorate social responsibility and sustainable business. Center for Creative Leadership.

Dahlsrud, A. (2008). How corporate social responsibility is definend: An analysis of 37 definitions. Corporate Social Responsibility \& Environmental Management, 15(1), 1-13.

Elkington, J. (1997). Cannibals with forks: the triple bottom line of the 21st century business Oxford: Capstone.

Fassin, Y., Van Rossem, A., \& Buelens, M. (2011). Small business owner-managers' perceptions of business ethis and CSRrelated concepts Journal of Business Ethics (98), 425-453.

Friedman, M. (1970). The social responsibilty of business is to increase profits. New York Times, 32-33.

Husted, B. W., \& Allen, D. B. (2007). Corporate social strategy in multinational enterprises: Antecedents and value creation. Journal of Business Ethics, 74(Spring), 345-361.

Jones, T. M. (1980). Corporate social responsibility revisited, redefined. California Management Review, 22(3), 59-67.

Leonard, D., \& McAdam, R. (2003). Corporate Social Responsibility. Quality Progress, (October), 27-32.

Matten, D., \& Moon, J. (2008). "Implicit" and "Explicit" CSR: A conceptual framework for a comparative understanding of Corporate Social Responsibility The Academy of Management Review, 33(2), 404-424.

MBA.com. (2014). Employers want communication skills in new hires. Retrieved 12/03/2016, 2016, from http://www.mba.com/us/the-gmat-blog-hub/the-official-gmat-blog/2014/aug/employers-want-communication-skills-innew-hires.aspx

McDonough, R. P., \& Bennett, M., S. (2006). Improving communication skills of pharmacy students through effective percepting. American Journal of Pharmaceutical Education, 70(3).

NASBA. (2008). Education and licensure requirements for Certified Public Accountants: A discussion regarding degreed candidates sitting for the uniform CPA Examination with a minimum of 120 credit hours (120-hour candidate) and becoming eligible for licensure with a minimum of 150 credit hours (150-hour candidate): (120/150 discussion), Draft report: National Association of State Boards of Accountancy.

Petcharat, N. N. (2014). Moving towards a more sustainable: CSR development in Thailand. Global Review of Accounting and Finance, 5(2), 16-35. 
Popular Pittsburgh. (2016). Pittsburgh's dark history. Retrieved 12/01/2016, 2016, from http://popularpittsburgh.com/darkhistory/

Schrotenboer, B. (2016, 05/07/2016). Livestrong adjusts to life without Lance Armstrong, USA Today. Retrieved from http://www.usatoday.com/story/sports/cycling/2016/05/04/livestrong-cancer-lance-armstrong-donations/83619386/

Sherman, W. R. (2002). Corporate social responsibility, corporate social performance \& sustainable stakeholder accounting. International Business \& Economics Research Journal, 1(3), 43-57.

Turnitin.com (2016). Accessed 12/20/2016.

Verschmoor, C. C. (2016). Global surveys measure nonfinancial reporting. Strategic Finance, October, 16-18.

Weygandt, J. J., Kimmel, P. D., \& Kieso, D. E. (2015). Managerial Accounting: Tools for business decision making (7th. ed.). Hoboken, New Jersey: Wiley. 
NOTES 